\title{
INFLATION AND ESTABLISHMENT TURNOVER
}

\author{
Gaetano Antinolfi \\ Washington University \\ and \\ David S. Kaplan \\ Instituto Tecnológico Autónomo de México (ITAM)
}

\section{INTRODUCTION}

Much macroeconomic research is devoted to the study of the relationship between inflation and real variables. Inflation operates through redistributive and price effects (including interest rates and wages) that affect economic decisions. We contribute to the study of this real-nominal link from a novel perspective, by considering the empirical relation between inflation and turnover. We analyze gross employment flows in continuing establishments, new establishments (births) and exiting establishments (deaths). The study of the link between gross employment flows and inflation has not been emphasized in the literature, which has traditionally focused on net employment flows. Our approach allows us to highlight another potential cost of inflation: its negative impact on entry and exit. Entry and exit (turnover) constitute an economic phenomenon that is fundamental to the process of economic change through their influence on productivity and growth.

We measure turnover through births and deaths of manufacturing establishments. Specifically, we consider labor creation due to the birth of new establishments relative to the total employment, and labor destruction due to the death of old establishments relative to the total employment. We study these variables with annual micro-level observations on establishment births, deaths, employment expansions and contractions, as well as observations on inflation, over the period 1973-1988. We document evidence of the following two relations: (i) Labor creation due to new establishments is negatively related to the rate of inflation. (ii) Labor destruction due to the deaths of old establishments is also negatively related to the rate of inflation. With an additional data source on business failures over the period 1968-1997, we show that a similar relation exists. That is, business failures exhibit negative correlation with the rate of inflation over that period.

Total labor creation is the addition to employment due to new and continuing establishments. Total labor destruction is the number of jobs lost due to both continuing and dying establishments (i.e. establishments that cease production). We find that the pattern of labor creation and destruction due to continuing establishments is correlated with the cyclical variation of output. However, the pattern of labor cre-

Gaetano Antinolfi: Department of Economics, Washington University, St. Louis, MO 63130. E-mail: gaetano@wustl.edu.

Eastern Economic Journal, Vol. 33, No. 3, Summer 2007 
ation and destruction due to births and deaths of establishments is not. This finding is consistent with the literature: for example, in a study on turnover based on firms, Scarpetta et al. [2002] find that the contribution of labor productivity of existing firms is related to the economic cycle. However, the contribution to total labor productivity growth of entry and exit of firms (net entry) is scarcely correlated to the business cycle, and quantitatively significant. ${ }^{1}$ This is an important difference because it indicates that the phenomenon we investigate is not a result of cyclical fluctuations. In fact, we provide evidence that both jobs created by establishment births and jobs destroyed by establishment deaths are negatively related to inflation, even after controlling for the effects of the real business cycle, monetary policy, and oil price shocks.

The organization of the rest of the paper is as follows. In the next section, we offer some theoretical motivation and discussion. In the following section, we describe our job creation and destruction data and present simple figures that are suggestive of our empirical results. In the section following that, we describe our empirical methodology and present our main empirical results. In the one following that, we present additional results intended as specification checks. Finally, we offer our conclusions and note some of the important questions that we cannot address with our data.

\section{THEORETICAL MOTIVATION AND DISCUSSION}

\section{Importance of Entry and Exit for the Economy}

Entry and exit are very important and much studied components of economic activity. Davis, Haltiwanger, and Schuh [1996] show that aggregate statistics for the United States mask important churning at the microeconomic level. They show, for instance, that large employment expansions and contractions occur at establishments in both strong and weak economies. Foster, Haltiwanger, and Krizan [1998] show that job reallocations due to expansions and contractions of establishments explain a significant share of aggregate productivity growth. These results are consistent with those of Scarpetta et al. [2002], who quantify the contribution of net entry to labor productivity growth between twenty and forty percent of total labor productivity growth. The importance of entries and exits is evident also for the stock market: Greenwood and Jovanovic [1999] show that new entrants (firms) account for a disproportionate share of the positive stock-market returns observed in the 1980's and 1990's.

Recent work suggests in particular important roles for establishment births and deaths: Spletzer [2000] shows that births and deaths account for roughly half of the job creation and destruction over a triennial time frame. Foster, Haltiwanger, and Krizan [1998] show that establishment births and deaths account for a significant share of aggregate productivity growth in certain service industries.

\section{Evidence on the Impact of Inflation}

The evidence of a relationship between inflation and establishment turnover suggests the existence of a link between the rate of inflation and the real economy. The idea that inflation affects real variables ${ }^{2}$ is supported by a wealth of evidence that inflation and the ex-ante return on saving are negatively related. Examples include 
Boudoukh and Richardson [1993], Fama and Schwert [1977] for stock-market effects and Kandel, Ofer, and Sarig [1996] and Fama [1990] for bond-market effects. There is also a rich literature investigating, both empirically and theoretically, the link between inflation and aggregate economic activity. Empirically, there is strong evidence indicating that high levels of inflation are extremely disruptive for economic activity. At low levels of inflation, however, the evidence is less clear-cut, and Bullard and Keating [1995], for example, document a positive long-run correlation between an increase in inflation and output, when the initial level of inflation is relatively low. ${ }^{3}$ Azariadis and Smith [1996], and Choi, Smith, and Boyd [1996], build models in which inflation may exacerbate financial-market frictions, and thus reduce real activity.

A particularly relevant theoretical piece is that of Tommasi [1999]. In this model, high inflation decreases the incentive for firms to increase productivity. An implication of Tommasi's model is that firm turnover is high following a successful inflation-stabilization program. In support of this link between inflation and turnover, we note also that there is evidence of significant labor reallocations following inflation-stabilization programs. Bruno and Meridor [1991] find that the successful 1985 Israeli inflationstabilization program led to an increase in firm bankruptcies and liquidations. Based on aggregate employment and output statistics, they conclude that labor must have been reallocated to other firms.

\section{Some Potential Explanations for an Inflation-Turnover Relationship}

What economic forces could explain the evidence on inflation and turnover? We discuss here three possible channels of transmission. Financial markets' interaction with inflation offers a potential explanation for the correlation between inflation and establishment turnover. It is plausible to assume that new firms (or new establishments) are more sensitive to credit conditions than existing firms (and establishments). Therefore, if inflation makes access to credit more difficult, ${ }^{4}$ turnover will be higher in periods of low inflation and lower in periods of high inflation. In other words, borrowing for the creation of new establishment would be more difficult with high inflation, which would protect existing establishment from the threat posed by new entrants, lowering exit at the same time. In addition, existing establishments may be less sensitive to credit-market conditions because of their history.

Acemoglu [2000] explores the link between credit market frictions and the turnover of firms. His paper develops the thesis that the high level of unemployment in Europe (as compared to the United States) can be explained by credit market inefficiencies. The thesis is that technological change generates fluctuations in unemployment that are harder to absorb when credit markets inefficiencies hinder the creation of new firms. Hence, in the language of our paper, credit market frictions may affect labor creation by new establishments, while at the same time hamper technological change and the turnover of firms. Note that the model of Acemoglu [2000] does not state that unemployment is caused by credit market frictions, rather it states that turnover is affected and unemployment harder to reabsorb, because of credit market frictions.

Another channel of transmission of inflation to the real economy that is often considered is the presence of nominal wage rigidities and their effect on the real-wage 
setting process. For example, surveys by Campbell and Kamlani [1997] indicate that firms are reluctant to make nominal-wage cuts, which accords with the econometric evidence from Altonji and Devereux [1999], Lebow, Saks, and Wilson [1999], Card and Hyslop [1997], and others who find that nominal-wage rigidities have important effects on wages. In our context, nominal-wage rigidities would become relevant if they affect the relative position of existing and entering establishments. To provide an example of this channel of transmission, consider the intuition of the model developed by Akerlof, Dickens and Perry [1996]. In their model wages are partially determined by bargaining, that is, owners and employees share the rents of their enterprises. Establishments in economic distress are therefore typically able to alleviate distress by lowering real wages. When inflation is low, establishments in economic distress cannot lower real wages without lowering nominal wages. This barrier may drive these establishments out of business, which makes room for new establishments to enter the market. These new establishments have an important advantage over existing establishments: they have no wage history behind them.

Finally, a third explanation of the relation between inflation and turnover relies on the effects of inflation on the environment in which firms compete and exercise market power. Imperfect competition plays a central role in many macroeconomic models. Inflation may affect market power and the price-setting process so that low turnover is observed when the inflation rate is high. Indeed, Chirinko and Fazzari [2000] find that inflation usually strengthens market power, and therefore may act as a barrier to entry. According to this view, high inflation would lower the capacity of new firms to compete with existing firms. Consequently, high inflation would be associated with low entry and low exit; vice versa low inflation, decreasing market power, would be associated with higher levels of entry and therefore exit. In summary, all channels presented, whether working through financial markets, labor markets, or imperfect competition, imply a negative relationship between inflation and turnover.

\section{DATA DESCRIPTION}

The job creation and destruction data used in this section can be downloaded from John Haltiwanger's web page at http://www.bsos.umd.edu/econ/haltiwanger/download. htm. We use two annual data sets that differ only in their levels of aggregation. Each of our data sets covers the manufacturing sector from 1973-88, and includes the following job creation and destruction variables:

1. The percent of total jobs that were created by new establishments.

2. The percent of total jobs that were created by existing establishments.

3. The percent of total jobs that were destroyed by dying establishments.

4. The percent of total jobs that were destroyed by continuing establishments.

We use aggregate data from the Census Bureau for the entire manufacturing sector ( $\mathrm{N}=16)$, as well as data aggregated at the two-digit industry level within nine regions ( $\mathrm{N}=2736)$, over the period $1973-88 .{ }^{5}$ We add the percent change in the consumer price index (urban unadjusted), the percent change in real GDP (chained 1992 dollars, seasonally adjusted), the percent change in the producer price index for crude oil (relative to the PPI for all commodities), and the real federal funds rate to our data. ${ }^{6}$ 
The denominator of all job creation and destruction variables is the average employment from the current and previous year. For example, the denominator for all job creation and destruction variables from aggregate 1973 data is the average of total manufacturing employment in March of 1972 and March of 1973. ${ }^{7}$ Our GDP, CPI, and oil-price measures use the more standard definition of percent change; the denominator is the previous year's level.

The job creation and destruction variables are measured as percent changes from March 12 of the previous year to March 12 of the current year. For example, 1973 data represent changes from March 12, 1972 to March 12, 1973. We attempt to match this time frame as closely as possible for all of our variables. We measure inflation and oil-price changes from March to March, GDP from the second quarter of the previous year through the first quarter of the current year, and the federal funds rate from March 13 of the previous year through March 12 of the current year.

Our CPI measure differs somewhat from official BLS figures. There have been important revisions to the calculation of the CPI in recent years, most notably the treatment of housing. Our measure of CPI, called CPI-UX1, matches CPI-U (urban unadjusted) exactly for calendar years 1983 on. For calendar years prior to 1983, CPI-UX1 incorporates the current methods for valuing homeowner costs, which significantly reduces measured inflation prior to 1983 .

Table 1 reports descriptive statistics for both of the job creation and destruction data sets used in this paper. Note that all of the variables exhibit considerable variation, making this time period ideal for our study. Fortunately, inflation is not highly correlated with the real-business cycle over this period, which allows us to separate the effects of inflation from the effects of the real-business cycle.

We plot inflation and the percent of total manufacturing jobs created by new establishments from 1973-88 in Figure 1. It is apparent that the two series are negatively correlated throughout the time period. Subsequent regressions will bolster this assertion. We plot inflation and the percent of total manufacturing jobs created by existing establishments in Figure 2. Note that the two series do not appear to be correlated. We further elaborate on this point by plotting the percent change in real GDP and the percent of total manufacturing jobs created by existing establishments in Figure 3, which shows that job creation by existing establishments is positively related to the real-business cycle.

Taken together, Figures 1-3 suggest that job creation from establishment births is negatively related to inflation, while job creation by existing establishments is positively related to the real-business cycle. We will show that the estimated impact of inflation on jobs created by births is essentially unchanged by including controls for the real-business cycle, as suggested by Figures 1-3.

Figures 4-6 are analogous to Figures 1-3, with job destruction by dying establishments and job destruction by continuing establishments substituted for the job creation variables in the earlier figures. Again, Figures 4-6 suggest that job destruction by dying establishments is negatively related to inflation. Job destruction by continuing establishments looks uncorrelated with inflation, but negatively correlated with the real-business cycle. We will show that the estimated impact of inflation on jobs destroyed by deaths is essentially unchanged by including controls for the real-business cycle, as suggested by Figures 4-6. 
TABLE 1

Descriptive Statistics

\begin{tabular}{|c|c|c|c|c|}
\hline \multicolumn{5}{|c|}{ Aggregate data for manufacturing (1973-88): $N=16$} \\
\hline Variable & Mean & Std. & Min. & Max. \\
\hline Percent of total jobs destroyed by dying establishments & 2.517 & 0.752 & 1.193 & 4.367 \\
\hline Percent of total jobs destroyed by continuing establishments & 7.836 & 2.629 & 4.368 & 13.804 \\
\hline Percent of total jobs created by new establishments & 1.441 & 0.496 & 0.611 & 2.306 \\
\hline Percent of total jobs created by existing establishments & 7.774 & 2.052 & 4.745 & 11.919 \\
\hline Percent change in consumer price index (urban unadjusted) & 6.309 & 2.806 & 2.256 & 12.011 \\
\hline Percent change in real (chained 1992 dollars) GDP & 3.057 & 2.579 & -1.427 & 6.591 \\
\hline Percent change in real oil prices & 3.294 & 23.585 & -40.947 & 50.235 \\
\hline Real federal funds rate & 2.608 & 3.100 & -1.181 & 8.932 \\
\hline \multicolumn{5}{|c|}{ Regional 2-digit industry data from manufacturing (9 regions, 19 industries, 1973-88): $N=273$} \\
\hline Variable & Mean & Std. & Min. & Max. \\
\hline Percent of total jobs destroyed by dying establishments & 2.734 & 2.742 & 0.000 & 52.032 \\
\hline Percent of total jobs destroyed by continuing establishments & 7.843 & 4.291 & 0.000 & 36.353 \\
\hline Percent of total jobs created by new establishments & 1.530 & 1.867 & 0.000 & 51.268 \\
\hline Percent of total jobs created by existing establishments & 8.073 & 3.840 & 0.000 & 46.210 \\
\hline Percent change in consumer price index (urban unadjusted) & 6.309 & 2.717 & 2.256 & 12.011 \\
\hline Percent change in real (chained 1992 dollars) GDP & 3.057 & 2.497 & -1.427 & 6.591 \\
\hline Percent change in real oil prices & 3.294 & 22.841 & -40.947 & 50.235 \\
\hline Real federal funds rate & 2.608 & 3.003 & -1.181 & 8.932 \\
\hline
\end{tabular}

Note: See text for more precise definitions of all variables

\section{FIGURE 1}

\section{Inflation and Percent of Manufacturing Jobs Created by New Establishments}

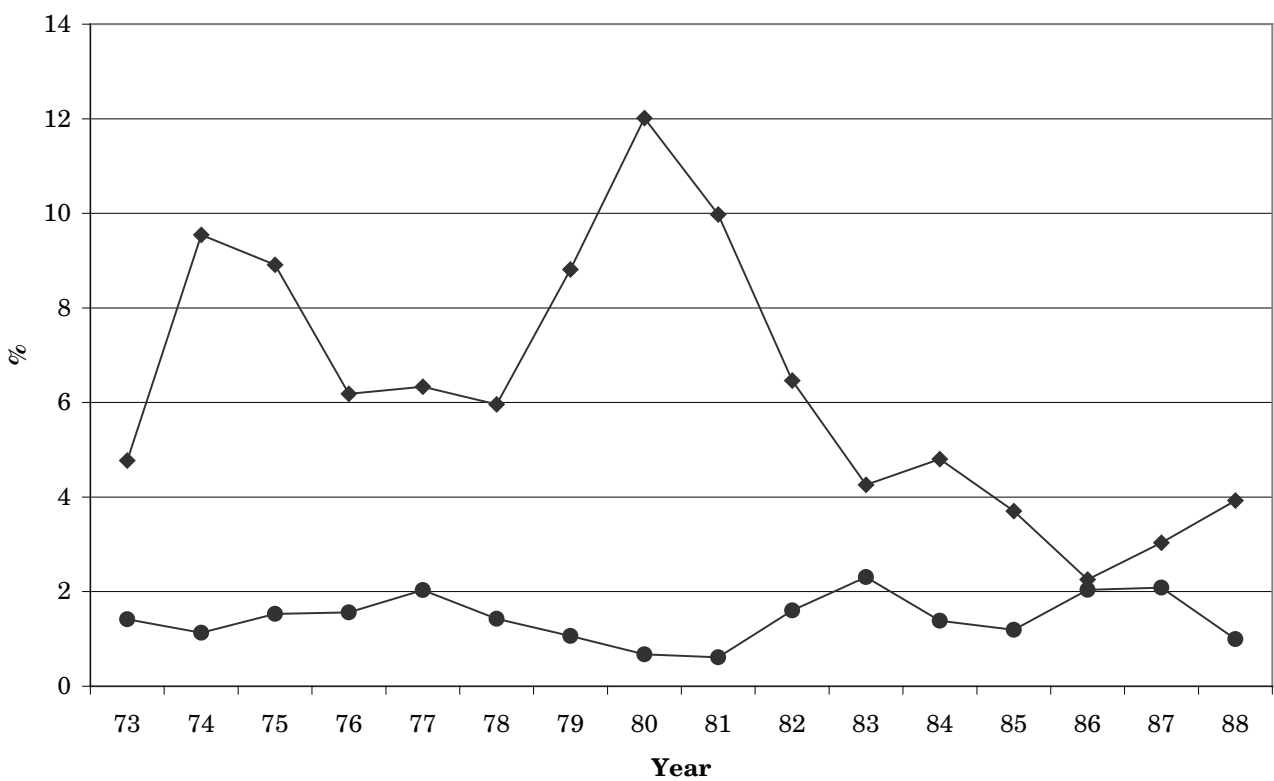

$\%$ of total jobs created by new estabs $-\bullet \%$ change in CPI 
FIGURE 2

Inflation and Percent of Manufacturing Jobs Created by

Existing Establishments

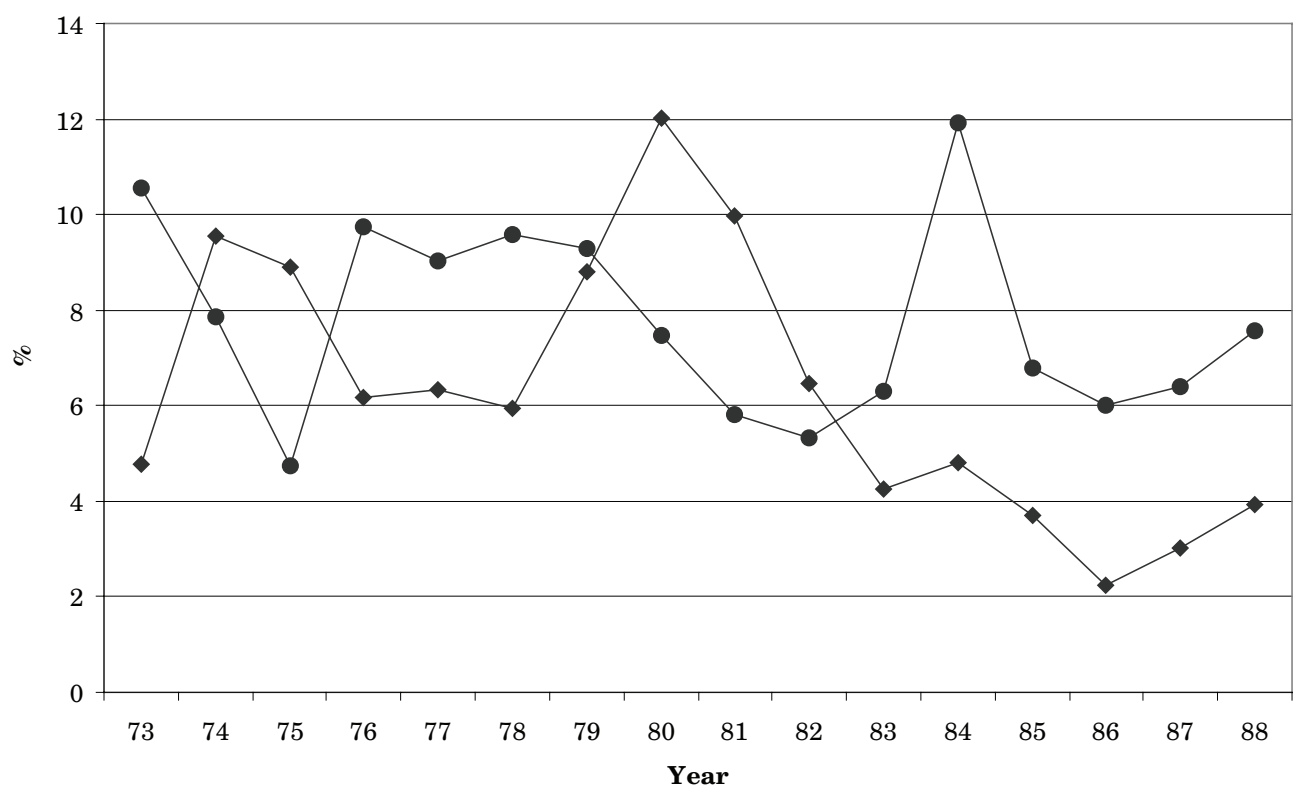

$\%$ of total jobs created by existing estabs $-\%$ change in CPI

FIGURE 3

Real GDP and Percent of Manufacturing Jobs Created by Existing Establishments

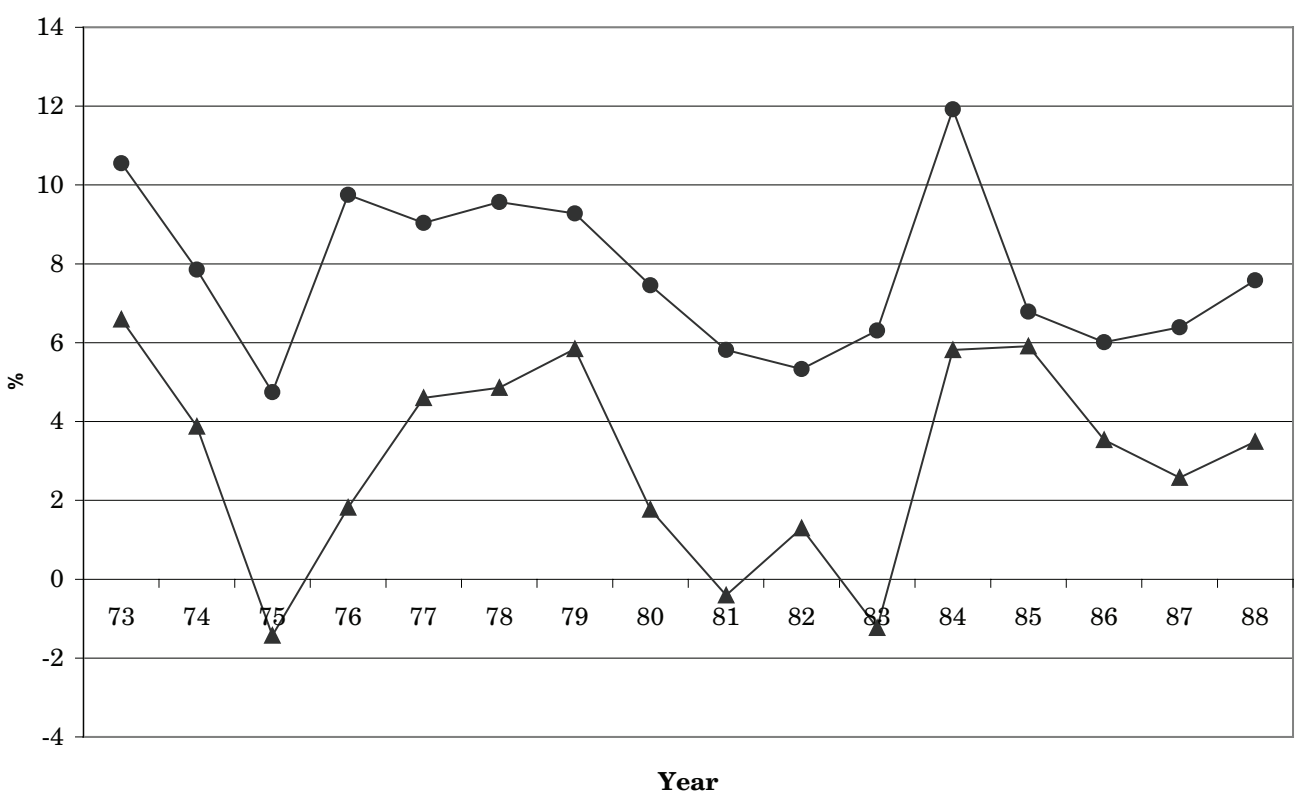

$\%$ of total jobs created by existing estabs $\neg \leftarrow \%$ change in real GDP 
FIGURE 4

Inflation and Percent of Manufacturing Jobs Destroyed by

Dying Establishments

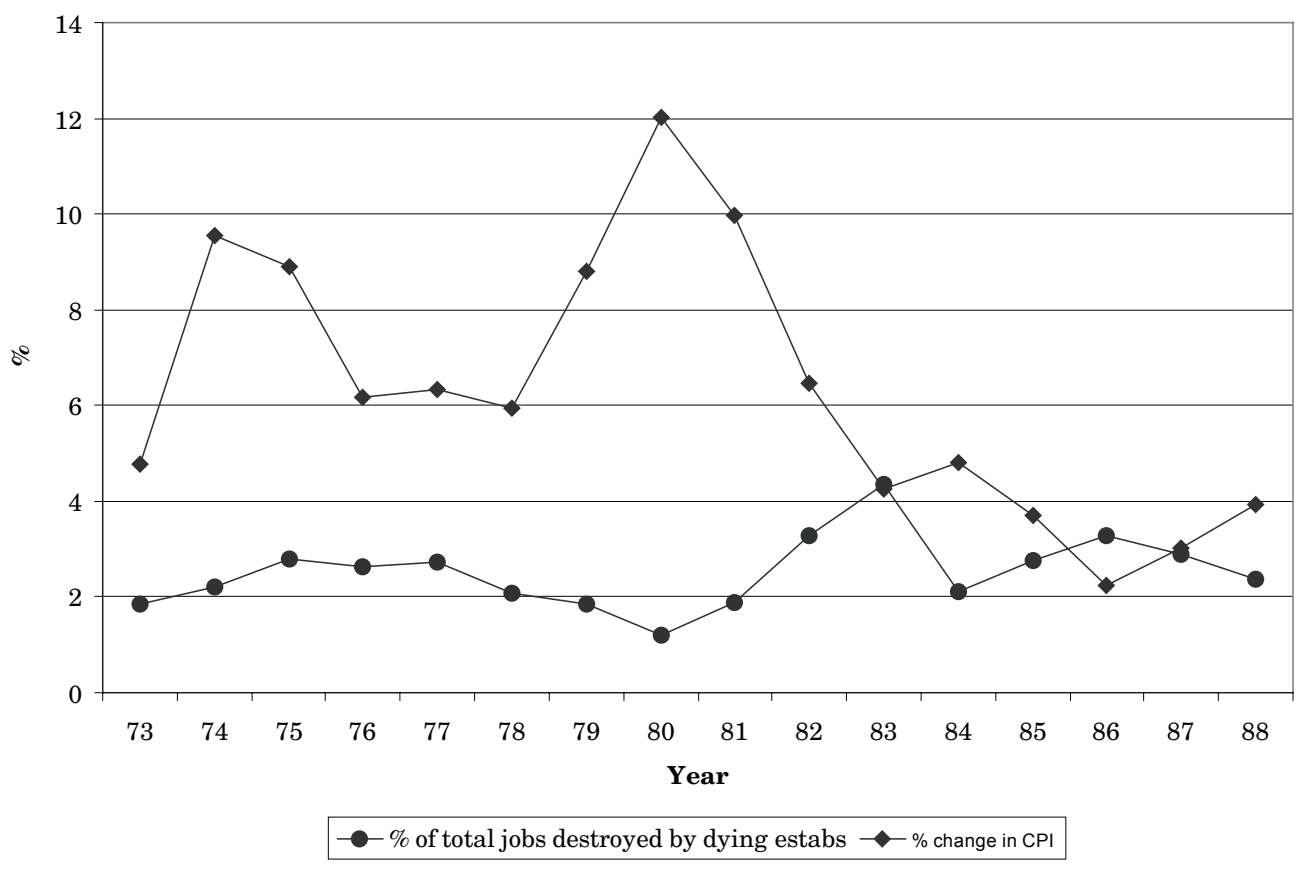

FIGURE 5

Inflation and Percent of Manufacturing Jobs Destroyed by Continuing Establishments

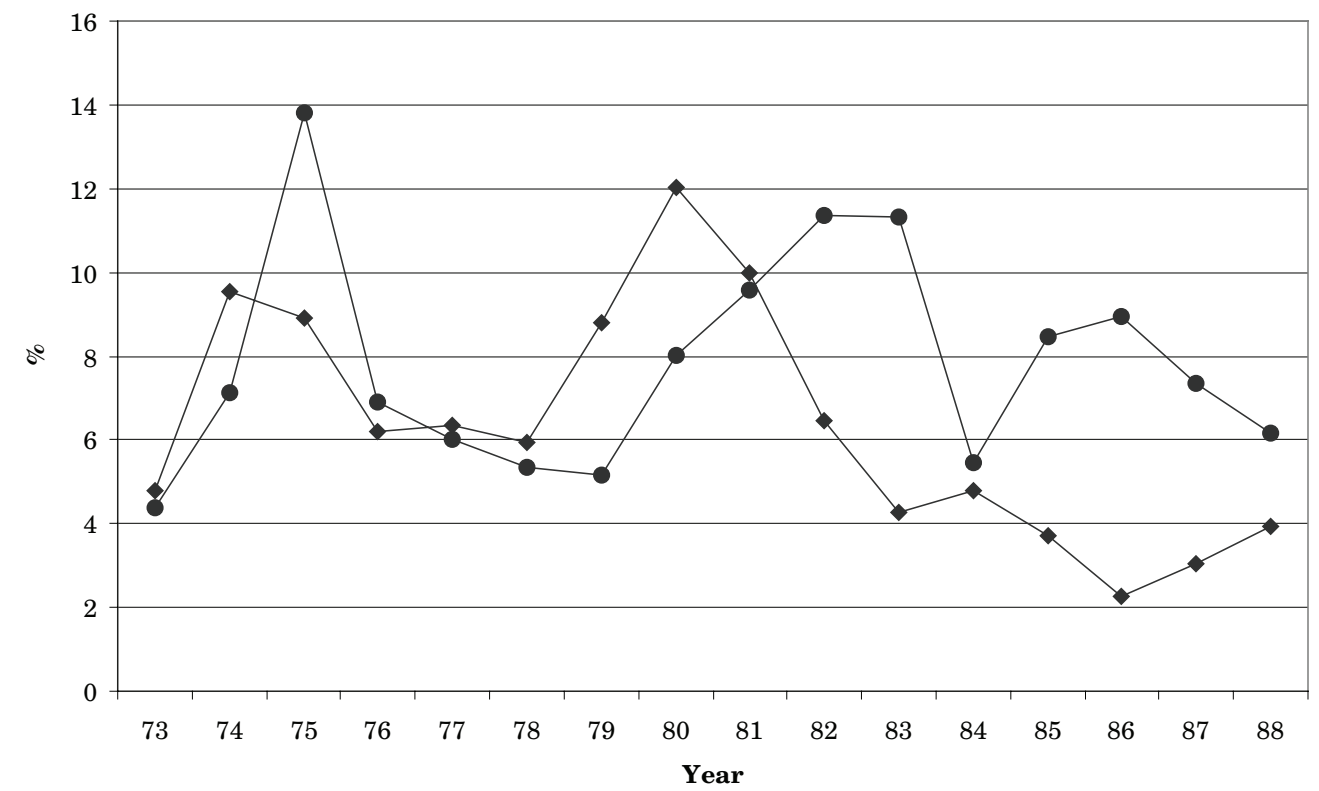

$\%$ of total jobs destroyed by continuing estabs $-\%$ change in CPI 
FIGURE 6

Real GDP and Percent of Manufacturing Jobs Destroyed by Continuing Establishments

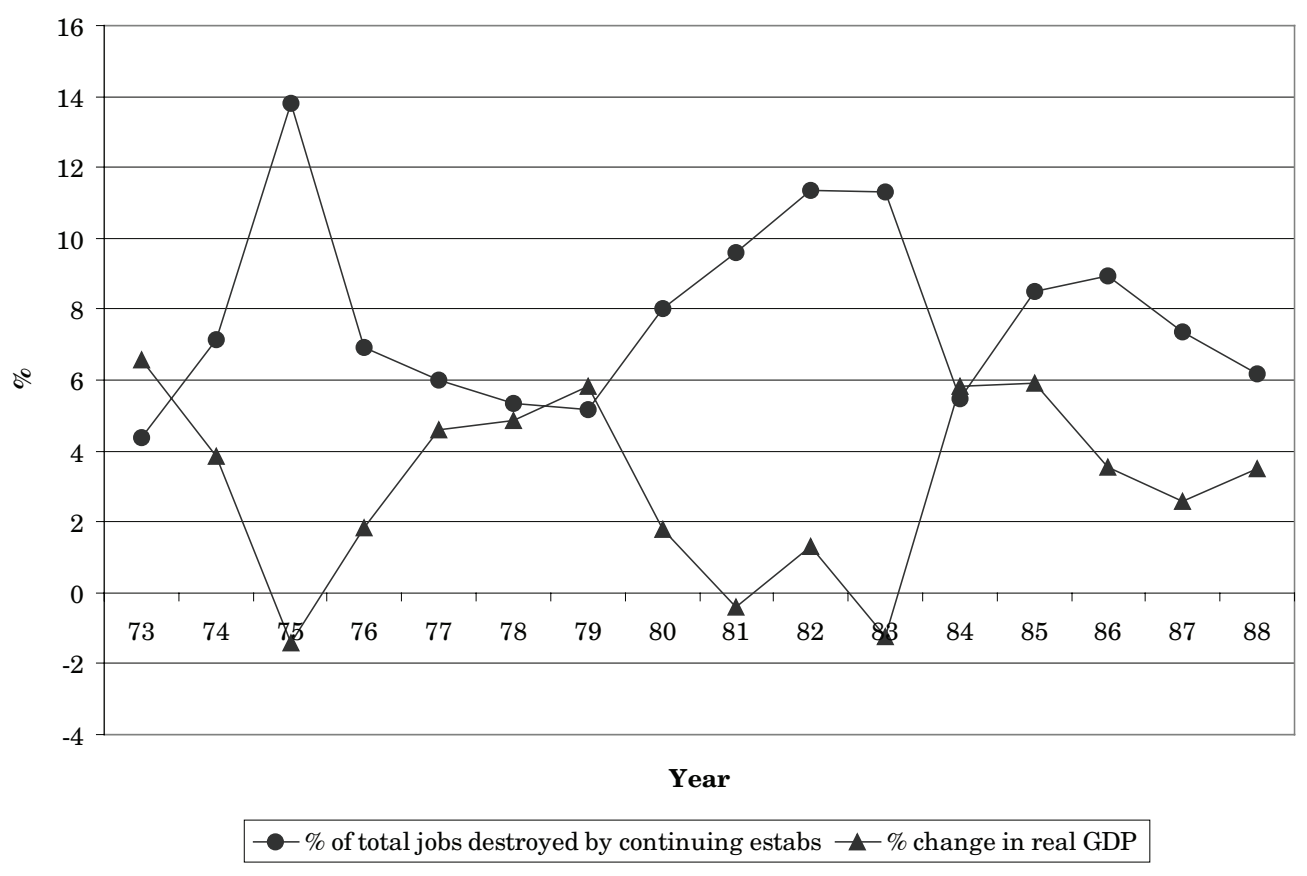

It is worthwhile at this stage to emphasize that inflation appears to be uncorrelated with the business cycle over this period. The contemporaneous correlation between inflation and percent changes in real GDP is -0.30 with a p-value of 0.26 . The $p$-value for a joint significance test is 0.34 when we include current and a one-year lag of real GDP and is 0.48 when we include current, a one-year lag, and a two-year lag of real GDP. We believe the absence of a correlation between inflation and the real business cycle makes this period ideal for studying the link between inflation and turnover.

\section{EMPIRICAL METHODOLOGY AND RESULTS}

When we use aggregate manufacturing data, our results come from simple regression models. When we use our disaggregated data set (19 industries and 9 regions), we need to worry about contemporaneous correlation of the error terms since key variables like inflation and GDP growth provide one observation per year. ${ }^{8}$ To address this concern, we assume a variance-covariance matrix of the form:

$$
\Omega=\left[\begin{array}{cccc}
\sigma_{1}^{2} I & \sigma_{12} I & \cdots & \sigma_{1 J} I \\
\sigma_{12} I & \sigma_{2}^{2} I & \cdots & \sigma_{2 J} I \\
\vdots & \vdots & \ddots & \vdots \\
\sigma_{1 J} I & \sigma_{2 J} I & \cdots & \sigma_{J}^{2} I
\end{array}\right]
$$


where each entry corresponds to a matrix (for 16 years of data) and $\mathrm{J}=171$ (the number of industry-region pairs). ${ }^{9}$ Under these assumptions, the covariance between the contemporaneous error terms of any two units is constant over time, but otherwise unrestricted. ${ }^{10}$ We use an estimate of $\Omega$ only for the purpose of correcting our standard errors; our point estimates come from ordinary least squares. ${ }^{11}$

We are now ready to present our empirical results. We have the following two empirical hypotheses:

1. The percent of jobs created by new establishments is negatively related to inflation, even after controlling for real-business cycle effects.

2. The percent of jobs destroyed by dying establishments is negatively related to inflation, even after controlling for real-business cycle effects.

\section{Aggregate Manufacturing Data}

The top panel of Table 2 shows estimates of the determinants of the percent of total manufacturing jobs created by new establishments. Note first that job creation by births is negatively correlated with inflation when inflation is the only explanatory variable. This relationship is statistically significant and large in magnitude. Note further that including the percent of jobs created by existing establishments and including the percent change in real GDP, which at least partially control for real-business cycle effects, does not weaken the inflation coefficient.

\section{TABLE 2}

The Effect of Inflation on Establishment Births and Deaths (aggregate manufacturing data, 1973-88)

Dependent Variable: Percent of Jobs Created By New Establishments

\begin{tabular}{lcccc}
\hline Variable & $\begin{array}{c}\text { Estimate } \\
\text { (Std. Error) }\end{array}$ & $\begin{array}{c}\text { Estimate } \\
\text { (Std. Error) }\end{array}$ & $\begin{array}{c}\text { Estimate } \\
\text { (Std. Error) }\end{array}$ & $\begin{array}{c}\text { Estimate } \\
\text { (Std. Error) }\end{array}$ \\
\hline intercept & 2.166 & 2.482 & 2.478 & 2.269 \\
& $(0.247)$ & $(0.295)$ & $(0.479)$ & $(0.472)$ \\
\% change in CPI & -0.115 & -0.133 & -0.117 & -0.137 \\
& $(0.036)$ & $(0.035)$ & $(0.037)$ & $(0.037)$ \\
\% change in real GDP & & -0.066 & & -0.090 \\
\% jobs created by existing estabs & & $(0.038)$ & & $(0.057)$ \\
Durbin-Watson statistic & & & -0.038 & 0.040 \\
R-squared & & & $(0.050)$ & $(0.069)$ \\
& 1.800 & 1.725 & 1.656 & 1.906 \\
\end{tabular}

Dependent Variable: Percent of Jobs Destroyed By Dying Establishments

\begin{tabular}{lcccc}
\hline Variable & $\begin{array}{c}\text { Estimate } \\
\text { (Std. Error) }\end{array}$ & $\begin{array}{c}\text { Estimate } \\
\text { (Std. Error) }\end{array}$ & $\begin{array}{c}\text { Estimate } \\
\text { (Std. Error) }\end{array}$ & $\begin{array}{c}\text { Estimate } \\
\text { (Std. Error) }\end{array}$ \\
\hline intercept & 3.493 & 4.394 & 2.181 & 2.908 \\
& $(0.402)$ & $(0.350)$ & $(0.373)$ & $(0.888)$ \\
\% change in CPI & -0.155 & -0.206 & -0.181 & -0.192 \\
& $(0.059)$ & $(0.042)$ & $(0.037)$ & $(0.039)$ \\
\% change in real GDP & & -0.188 & & -0.070 \\
& & $(0.046)$ & & $(0.078)$ \\
\% jobs destr by continuing estabs & & & 0.189 & 0.133 \\
& & & $(0.040)$ & $(0.074)$ \\
Durbin-Watson statistic & 1.617 & 2.038 & 2.097 & 2.103 \\
R-squared & 0.333 & 0.712 & 0.757 & 0.773 \\
\hline Notes: 16 observations. See text for
\end{tabular}

Notes: 16 observations. See text for details. 


\section{FIGURE 7}

Percent of Manufacturing Jobs Created by New Establishments Predicted vs Actual Values

(model controls for \% jobs created by existing estabs and real GDP growth)

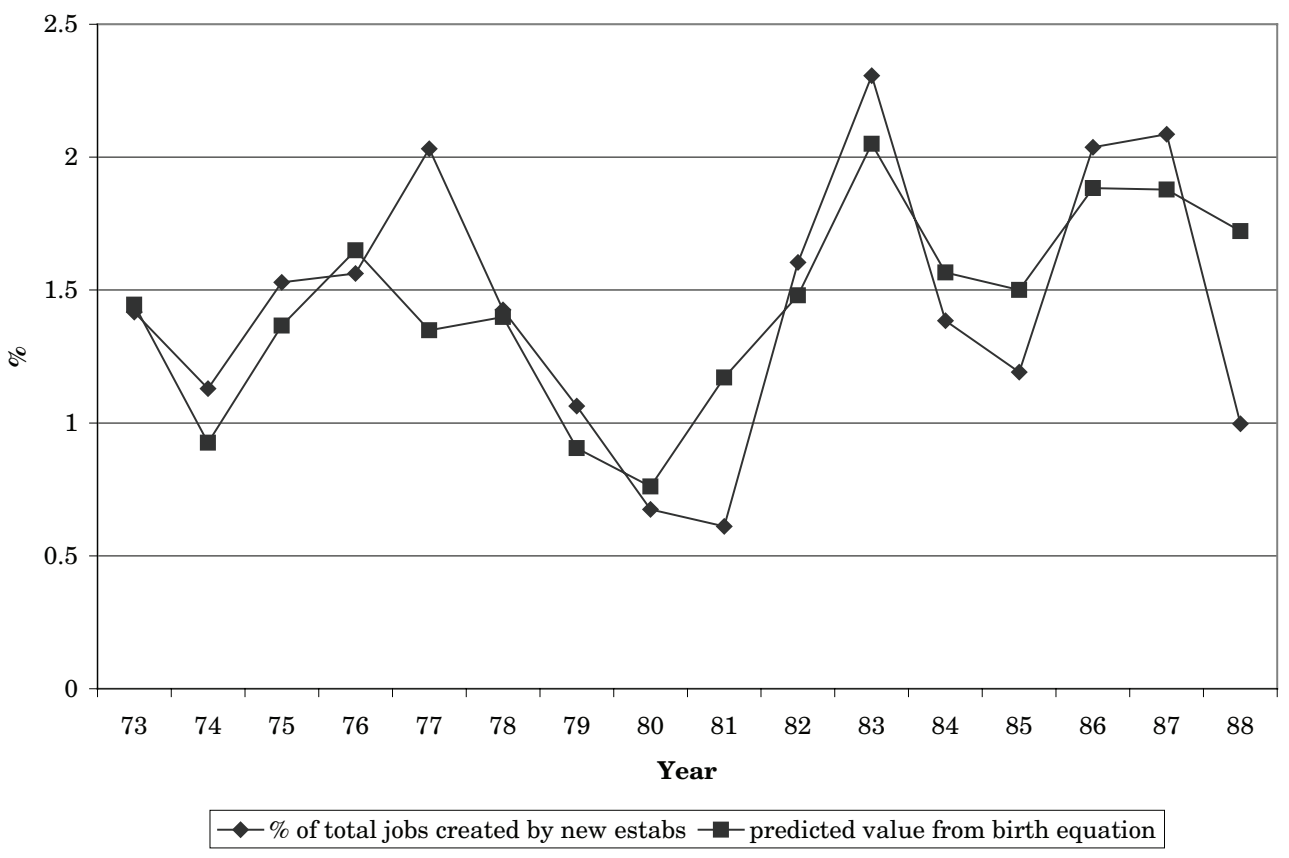

FIGURE 8

Percent of Manufacturing Jobs Destroyed by Dying Establishments Predicted vs Actual Values

(model controls for \% jobs destroyed by continuing estabs and real GDP growth)

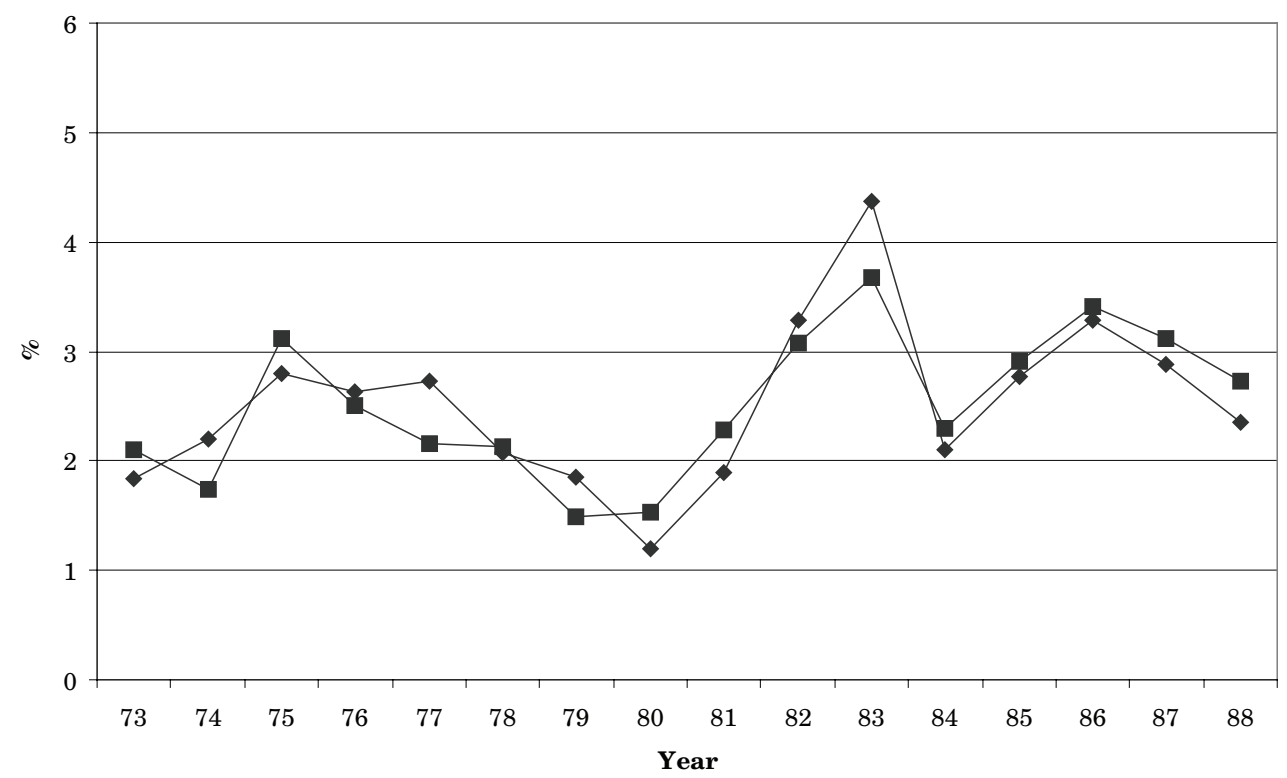

$\%$ of total jobs destroyed by dying estabs - predicted value from death equation 
The bottom panel of Table 2 shows, with similar results, analogous estimates for job destruction by dying establishments. When inflation is included as the only independent variable, its coefficient is negative, statistically significant, and large in magnitude. Again, including controls for the real-business cycle does not weaken the inflation coefficient.

Figure 7 plots actual and predicted values from the model in which the percent of jobs created by births is regressed on inflation, the percent change in real GDP, and the percent of jobs created by existing establishments. The model appears well specified throughout our sample period. Figure 8 plots actual and predicted values from the analogous death equation; again the model appears well specified throughout the time period.

\section{Regional Data}

Although results for the manufacturing sector as a whole are interesting, much more can be learned from disaggregated data. Table 3 uses data from 19 two-digit manufacturing industries and 9 regions from 1973-88 to re-estimate birth and death equations of the form estimated in Table 2, adding fixed industry and fixed region effects as additional controls. ${ }^{12}$ Note that, for both the birth models and the death models, the inflation coefficients are quite similar to those reported in Table 2. Specifically, the inflation coefficients are negative, large, statistically significant, and not weakened by real-business-cycle controls.

TABLE 3

The Effect of Inflation on Establishment Births and Deaths

(2-digit manufacturing industries by region, 1973-88)

Dependent Variable: Percent of Jobs Created By New Establishments

\begin{tabular}{lcccc}
\hline Variable & $\begin{array}{c}\text { Estimate } \\
\text { (Std. Error) }\end{array}$ & $\begin{array}{c}\text { Estimate } \\
\text { (Std. Error) }\end{array}$ & $\begin{array}{c}\text { Estimate } \\
\text { (Std. Error) }\end{array}$ & $\begin{array}{c}\text { Estimate } \\
\text { (Std. Error) }\end{array}$ \\
\hline \% change in CPI & -0.116 & -0.132 & -0.116 & -0.136 \\
& $(0.040)$ & $(0.039)$ & $(0.041)$ & $(0.039)$ \\
\% change in real GDP & & -0.057 & & -0.075 \\
& & $(0.044)$ & & $(0.043)$ \\
\% jobs created by existing estabs & & & 0.009 & 0.030 \\
& & & $(0.023)$ & $(0.021)$ \\
R-squared & 0.131 & 0.136 & 0.131 & 0.139
\end{tabular}

Dependent Variable: Percent of Jobs Destroyed By Dying Establishments

\begin{tabular}{lcccc}
\hline Variable & $\begin{array}{c}\text { Estimate } \\
\text { (Std. Error) }\end{array}$ & $\begin{array}{c}\text { Estimate } \\
\text { (Std. Error) }\end{array}$ & $\begin{array}{c}\text { Estimate } \\
\text { (Std. Error) }\end{array}$ & $\begin{array}{c}\text { Estimate } \\
\text { (Std. Error) }\end{array}$ \\
\hline \% change in CPI & -0.162 & -0.217 & -0.171 & -0.214 \\
& $(0.064)$ & $(0.048)$ & $(0.052)$ & $(0.047)$ \\
\% change in real GDP & & -0.199 & & -0.181 \\
& & $(0.052)$ & & $(0.056)$ \\
\% jobs destr by continuing estabs & & & 0.074 & 0.022 \\
& & & $(0.023)$ & $(0.023)$ \\
R-squared & 0.180 & 0.210 & 0.192 & 0.211
\end{tabular}

Notes: 2736 observations from 19 manufacturing industries, 9 regions, and 16 years. All standard errors are robust to contemporaneous correlation of the error terms across industry-region pairs. Fixed industry and fixed region effects included but not shown. See text for details. 
To control further for real-business cycle effects in our birth models, we use oneand two-year lags of jobs created by existing establishments as additional controls. We do not include lags of real GDP because we are reluctant to add more variables without cross-sectional variability. We present these results in the top panel of Table 4, which shows that the lags do not have much explanatory power and do not have much of an impact on the inflation coefficient..$^{13}$

Similarly, we use one- and two-year lags of jobs destroyed by continuing establishments as additional controls for our death models, and present these estimates in the bottom panel of Table 4. Lags of job destruction by continuing establishments do have significant explanatory power in the death equation, but they do not have much of an impact on the inflation coefficient.

\section{TABLE 4}

The Effect of Inflation on Establishment Births and Deaths (2-digit manufacturing industries by region, 1975-88)

\begin{tabular}{lcccc} 
Dependent Variable: Percent of Jobs Created By New Establishments \\
\hline Variable & $\begin{array}{c}\text { Estimate } \\
\text { (Std. Error) }\end{array}$ & $\begin{array}{c}\text { Estimate } \\
\text { (Std. Error) }\end{array}$ & $\begin{array}{c}\text { Estimate } \\
\text { (Std. Error) }\end{array}$ & $\begin{array}{c}\text { Estimate } \\
\text { (Std. Error) }\end{array}$ \\
\hline \% change in CPI & -0.123 & -0.143 & -0.132 & -0.164 \\
& $(0.046)$ & $(0.045)$ & $(0.046)$ & $(0.044)$ \\
\% change in real GDP & & -0.068 & -0.101 \\
& & $(0.050)$ & & $(0.049)$ \\
\% jobs created by existing estabs & & & 0.010 & 0.033 \\
& & & $(0.027)$ & $(0.023)$ \\
\% jobs created by existing estabs & & & 0.006 & 0.028 \\
$\quad$ (one-year lag) & & & $(0.027)$ & $(0.024)$ \\
\% jobs created by existing estabs & & & 0.023 & 0.017 \\
$\quad$ two-year lag) & & & $(0.027)$ & $(0.024)$ \\
R-squared & 0.119 & 0.126 & 0.122 & 0.133
\end{tabular}

Dependent Variable: Percent of Jobs Destroyed By Dying Establishments

\begin{tabular}{lcccc}
\hline Variable & $\begin{array}{c}\text { Estimate } \\
\text { (Std. Error) }\end{array}$ & $\begin{array}{c}\text { Estimate } \\
\text { (Std. Error) }\end{array}$ & $\begin{array}{c}\text { Estimate } \\
\text { (Std. Error) }\end{array}$ & $\begin{array}{c}\text { Estimate } \\
\text { (Std. Error) }\end{array}$ \\
\hline \% change in CPI & -0.177 & -0.234 & -0.145 & -0.190 \\
& $(0.068)$ & $(0.053)$ & $(0.057)$ & $(0.052)$ \\
\% change in real GDP & & -0.199 & -0.173 \\
& & $(0.059)$ & $(0.062)$ \\
\% jobs destr by continuing estabs & & & 0.057 & 0.017 \\
& & & $(0.024)$ & $(0.023)$ \\
\% jobs destr by continuing estabs & & & 0.081 & 0.056 \\
(one-year lag) & & & $0.024)$ & $(0.022)$ \\
\% jobs destr by continuing estabs & & & 0.027 & 0.044 \\
$\quad$ (two-year lag) & & & $0.025)$ & $(0.024)$ \\
R-squared & & & 0.207 & 0.221 \\
\hline
\end{tabular}

Notes: 2394 observations from 19 manufacturing industries, 9 regions, and 14 years. All standard errors are robust to contemporaneous correlation of the error terms across industry-region pairs. Fixed industry and fixed region effects included but not shown. See text for details.

Figure 9 is the analogue of Figure 7, and plots yearly averages of actual and predicted values from the birth equation in Table 4 that includes real GDP growth and current through two-year lags of jobs created by existing establishments as controls. Figure 10 plots yearly averages of actual and predicted values from the analogous 
death equation. Our results on the effects of inflation on establishment births and deaths remain strong after adding additional real-business-cycle controls.

\section{FIGURE 9}

Averages of Predicted and Actual Percent of Jobs Created by Births (model controls for inflation, GDP growth, current through two-year lags of jobs created by existing estabs, fixed industry effects, and fixed region effects)

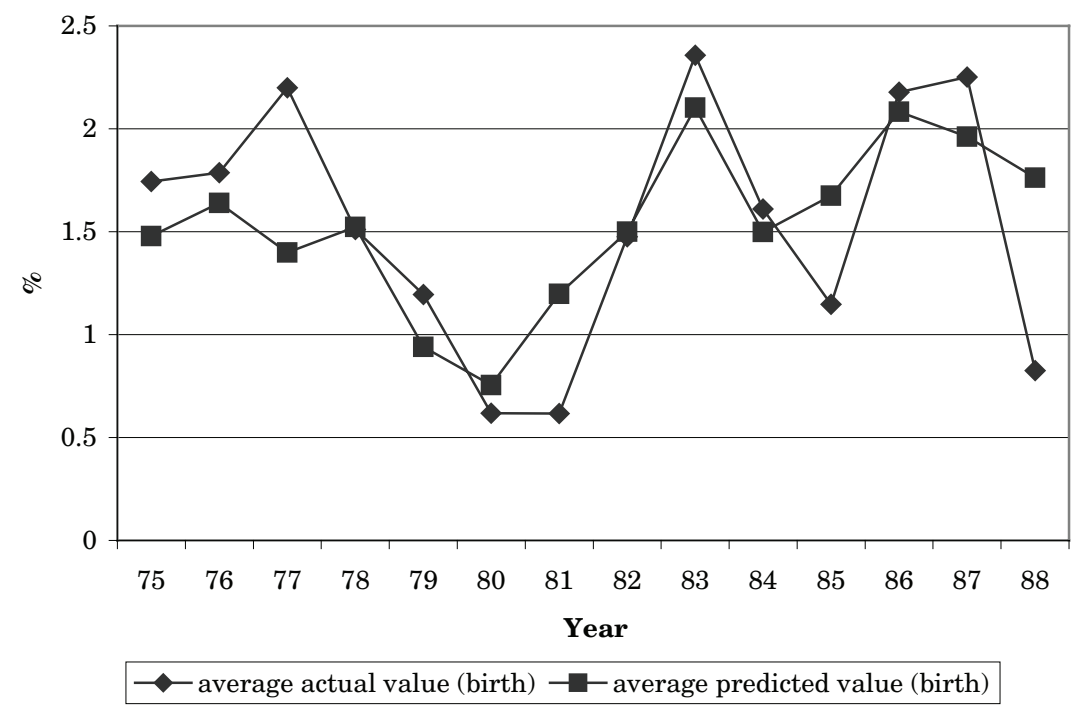

\section{FIGURE 10}

Averages of Predicted and Actual Percent of Jobs Destroyed by Deaths (model controls for inflation, GDP growth, current through two-year lags of jobs destroyed by continuing estabs, fixed industry effects, and fixed region effects)

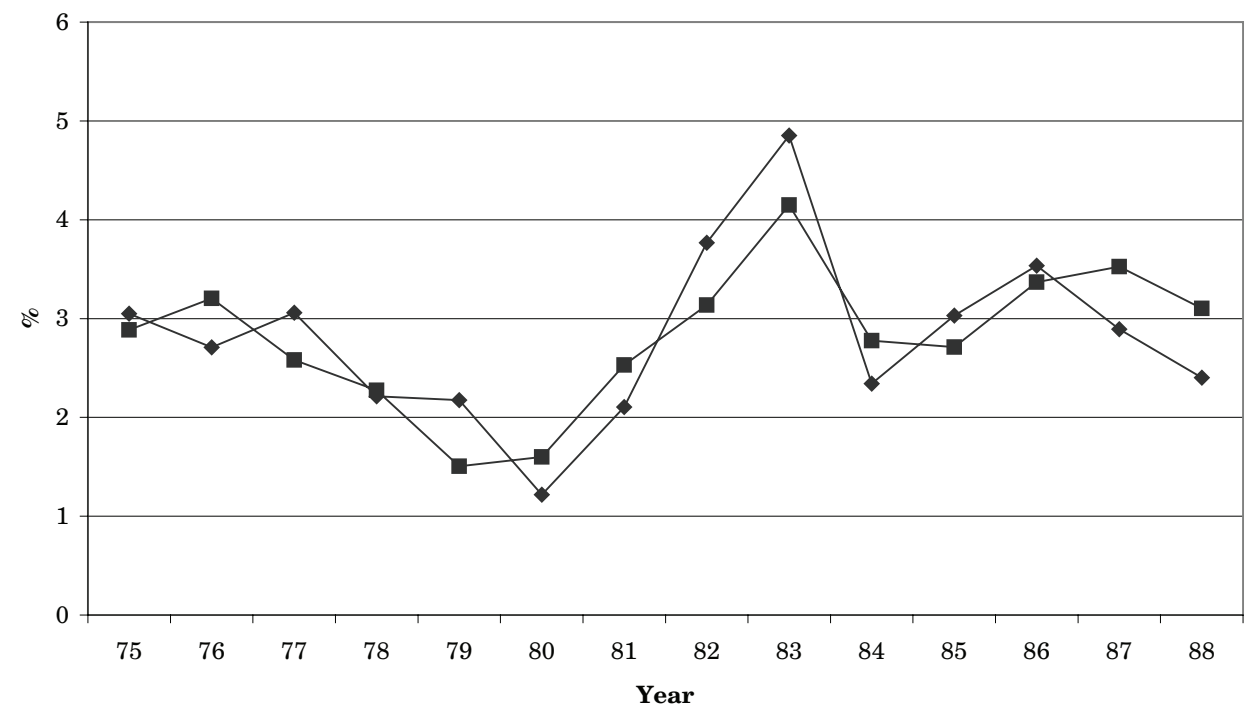


Overall, we believe Tables 2-4, along with Figures 1-10 offer strong evidence that both jobs created by new establishments and jobs destroyed by dying establishments are negatively related to inflation, and that these relationships are not driven by the real-business cycle.

\section{SPECIFICATION CHECKS}

We consider the following four possible criticisms of the results presented in the previous section:

1. Inflation proxies for the effect of oil-price shocks.

2. Our results are not robust throughout our sample period.

3. Inflation proxies for the effects of monetary policy.

4. Our results are not robust across industries and regions.

\section{Oil-price shocks and robustness over time}

We follow Hamilton [1999] and use the producer price index for crude petroleum as our oil-price measure, although we normalize the measure by dividing by the producer price index for all commodities. More specifically, our oil-price measure is the percent change, from March of the previous year to March of the current year, in the producer price index for crude petroleum divided by the producer price index for all commodities.

Not surprisingly, the percent change in the consumer price index and our oil-price measure are highly correlated; the correlation coefficient between the two series is 0.78. It is therefore quite difficult for us to separate the effects of inflation from the effects of oil prices, although we believe oil-price shocks are unlikely candidates to explain our results.

The top panel of Table 5 shows the results from birth equations estimated on disaggregated data, including real GDP growth and current through two-year lags of job creation in existing establishments as real-business cycle controls. Note that both inflation and oil-price shocks have negative and statistically significant coefficients when entered individually. When entered together, neither coefficient is significant at the 0.05 level.

The bottom panel of Table 5 shows the results from the analogous death equations. Once again, both inflation and oil-price shocks have negative and statistically significant coefficients when entered individually. When entered together, the inflation coefficient becomes statistically insignificant while the oil-price coefficient remains negative and strong.

How should we interpret these results? We believe the only sensible interpretation of the birth results is that the data cannot distinguish between the effects of inflation and oil prices. The death results imply that inflation does not affect deaths, and merely proxies for oil-price shocks. We believe, however, that this negative coefficient for oil-prices is extremely counterintuitive; why would oil-price increases lead to fewer deaths? We therefore believe that the strength of the oil prices in the death equation is more likely to reflect functional form than a true oil-price effect. 
TABLE 5

The Effect of Inflation and Oil Prices on Establishment Births and Deaths (2-digit manufacturing industries by region, 1975-88)

\begin{tabular}{lccc} 
Dependent Variable: Percent of Jobs Created By New Establishments & \\
\hline Variable & $\begin{array}{c}\text { Estimate } \\
\text { (Std. Error) }\end{array}$ & $\begin{array}{c}\text { Estimate } \\
\text { (Std. Error) }\end{array}$ & $\begin{array}{c}\text { Estimate } \\
\text { (Std. Error) }\end{array}$ \\
\hline \% change in CPI & -0.164 & & -0.121 \\
& $(0.044)$ & & $(0.065)$ \\
\% change in real oil prices & & -0.019 & -0.007 \\
& & $(0.006)$ & $(0.009)$ \\
\% change in real GDP & -0.101 & -0.089 & -0.106 \\
& $(0.049)$ & $(0.051)$ & $(0.048)$ \\
\% jobs created by existing estabs & 0.033 & 0.033 & 0.035 \\
& $(0.023)$ & $(0.024)$ & $(0.022)$ \\
\% jobs created by existing estabs & 0.028 & 0.020 & 0.029 \\
(one-year lag) & $(0.024)$ & $(0.025)$ & $(0.023)$ \\
\% jobs created by existing estabs & 0.017 & -0.004 & 0.011 \\
(two-year lag) & $(0.024)$ & $(0.026)$ & $(0.024)$ \\
R-squared & 0.133 & 0.125 & 0.135
\end{tabular}

Dependent Variable: Percent of Jobs Destroyed By Dying Establishments

\begin{tabular}{lccc}
\hline Variable & $\begin{array}{c}\text { Estimate } \\
\text { (Std. Error) }\end{array}$ & $\begin{array}{c}\text { Estimate } \\
\text { (Std. Error) }\end{array}$ & $\begin{array}{c}\text { Estimate } \\
\text { (Std. Error) }\end{array}$ \\
\hline \% change in CPI & -0.190 & & -0.052 \\
& $(0.052)$ & $0.064)$ \\
\% change in real oil prices & & -0.029 & -0.024 \\
& & $(0.006)$ & $(0.008)$ \\
\% change in real GDP & -0.173 & -0.193 & -0.197 \\
& $(0.062)$ & $(0.052)$ & $(0.051)$ \\
\% jobs destr by continuing estabs & 0.017 & 0.001 & 0.002 \\
& $(0.023)$ & $(0.021)$ & $(0.021)$ \\
\% jobs destr by continuing estabs & 0.056 & 0.059 & 0.055 \\
(one-year lag) & $(0.022)$ & $(0.019)$ & $(0.019)$ \\
\% jobs destr by continuing estabs & 0.044 & 0.063 & 0.057 \\
(two-year lag) & $(0.024)$ & $(0.021)$ & $(0.020)$ \\
R-squared & 0.221 & 0.231 & 0.232 \\
\hline
\end{tabular}

Notes: 2394 observations from 19 manufacturing industries, 9 regions, and 14 years. All standard errors are robust to contemporaneous correlation of the error terms across industry-region pairs. Fixed industry and fixed region effects included but not shown. See text for details.

Previous studies on the effects of oil prices might help us distinguish between the effects of inflation and oil-price shocks. Numerous studies have found that oil-price shocks have asymmetric effects; oil-price increases have important macroeconomic effects, but oil-price decreases may not. ${ }^{14}$ Davis and Haltiwanger [1996; 1999] also found a non-linear relationship using job creation and destruction data where births are aggregated with expansions and deaths are aggregated with contractions.

Oil-prices fell six out of seven years from 1982-1988. If inflation has no impact on births and deaths, and merely proxies for oil-price shocks, we would not expect a strong relationship over this period of declining oil prices. We address this issue, for both a birth and a death model, in Table 6 by estimating separate inflation coefficients for the 1975-81 period and for the 1982-88 period. This robustness check would be useful even if oil-price shocks were not a concern. 
TABLE 6

\section{Testing for Changes in the Inflation Coefficients Over Time}

(2-digit manufacturing industries by region, 1975-88)

\begin{tabular}{lcccc}
\hline & \multicolumn{2}{c}{ Birth Equation } & \multicolumn{2}{c}{ Death Equation } \\
Variable & Estimate & Std. Error & Estimate & Std. Error \\
\hline \% change in CPI (1975-1981) & -0.198 & 0.052 & -0.169 & 0.064 \\
\% change in CPI (1982-1988) & -0.274 & 0.102 & -0.125 & 0.123 \\
Test for equality of inflation & $\mathrm{t}=1.23$ & & $\mathrm{t}=0.60$ & \\
coefficients for the two periods & & & & \\
\% change in real GDP & -0.107 & 0.048 & -0.169 & 0.062 \\
\% jobs created by existing estabs & 0.028 & 0.022 & & \\
$\quad$ one-year lag & 0.025 & 0.023 & & \\
$\quad$ two-year lag & 0.007 & 0.024 & & 0.014 \\
\% jobs destr by continuing estabs & & & 0.056 & 0.022 \\
$\quad$ one-year lag & & & 0.041 & 0.024 \\
$\quad$ two-year lag & & & 0.222 & \\
R-squared & 0.137 & & & \\
\hline
\end{tabular}

Notes: 2394 observations from 19 manufacturing industries, 9 regions, and 14 years. Standard errors are robust to contemporaneous correlation of the error terms across industry-region pairs. Fixed industry and fixed region effects included but not shown. See text for details.

Birth equation: Dependent variable is the percent of the industry's regional employment created by new establishments.

Death equation: Dependent variable is the percent of the industry's regional employment destroyed by dying establishments.

Looking at the birth equation in Table 6, we see the inflation coefficient is estimated to be stronger during the period of declining oil prices, although the difference is statistically insignificant. The death equation yields a slightly weaker inflation coefficient during the period of declining oil prices; once again this difference is statistically insignificant. Overall, we view the robustness of our results during a period of declining oil prices as evidence that inflation is more than a proxy for oil-price shocks.

\section{Monetary policy}

We use the real federal funds rate from March 13 of the previous year through March 12 of the current year to investigate the effects of monetary policy. ${ }^{15}$ Two features are important to notice: monetary policy is not highly correlated with inflation over this period (the correlation coefficient is 0.46 ), and monetary policy was tightened severely in the early 1980 s.

The top panel of Table 7 shows the results from birth equations estimated on disaggregated data, including real GDP growth and current through two-year lags of job creation in existing establishments as real-business cycle controls. Note that the real federal funds rate does not have a significant impact on births whether inflation is included in the model or not. We also use one- and two-year lags of the federal funds rate to control for the lagged effect of monetary policy. In this case, the coefficients on the federal funds rate variables are significant, but the estimated coefficient on CPI inflation is not much affected.

The bottom panel of Table 7 presents the analogous death estimates. Note that the coefficient for the real federal funds rate is statistically significant when inflation 
is left out of the model. When inflation is included, the federal-funds-rate coefficient loses statistical significance. The inflation coefficient, however, remains strong when the real federal funds rate is included as a control. Again, we include one- and twoyear lags of the federal funds rate to control for the delayed effect of monetary policy. In this case, only the two-year lag of the federal funds rate coefficients is significant, whereas the coefficient on CPI inflation remains unaffected.

\section{TABLE 7}

The Effect of Inflation and Monetary Policy on Establishment Births and Deaths (2-digit manufacturing industries by region, 1975-88)

\section{Dependent Variable: Percent of Jobs Created By New Establishments}

\begin{tabular}{|c|c|c|c|c|}
\hline Variable & $\begin{array}{c}\text { Estimate } \\
\text { (Std. Error) }\end{array}$ & $\begin{array}{c}\text { Estimate } \\
\text { (Std. Error) }\end{array}$ & $\begin{array}{c}\text { Estimate } \\
\text { (Std. Error) }\end{array}$ & $\begin{array}{c}\text { Estimate } \\
\text { (Std. Error) }\end{array}$ \\
\hline$\%$ change in CPI & $\begin{array}{l}-0.164 \\
(0.044)\end{array}$ & & $\begin{array}{l}-0.204 \\
(0.050)\end{array}$ & $\begin{array}{l}-0.180 \\
(0.053)\end{array}$ \\
\hline real federal funds rate & & $\begin{array}{c}0.026 \\
(0.051)\end{array}$ & $\begin{array}{l}-0.066 \\
(0.043)\end{array}$ & $\begin{array}{l}-0.122 \\
(0.048)\end{array}$ \\
\hline $\begin{array}{l}\text { real federal funds rate } \\
\quad \text { (one-year lag) }\end{array}$ & & & & $\begin{array}{c}0.171 \\
(0.074)\end{array}$ \\
\hline $\begin{array}{l}\text { real federal funds rate } \\
\quad \text { (two-year lag) }\end{array}$ & & & & $\begin{array}{l}-0.122 \\
(0.055)\end{array}$ \\
\hline R-squared & 0.133 & 0.092 & 0.139 & 0.152 \\
\hline \multicolumn{5}{|c|}{ Dependent Variable: Percent of Jobs Destroyed By Dying Establishments } \\
\hline Variable & $\begin{array}{c}\text { Estimate } \\
\text { (Std. Error) }\end{array}$ & $\begin{array}{c}\text { Estimate } \\
\text { (Std. Error) }\end{array}$ & $\begin{array}{c}\text { Estimate } \\
\text { (Std. Error) }\end{array}$ & $\begin{array}{c}\text { Estimate } \\
\text { (Std. Error) }\end{array}$ \\
\hline$\%$ change in CPI & $\begin{array}{l}-0.190 \\
(0.052)\end{array}$ & & $\begin{array}{l}-0.148 \\
(0.060)\end{array}$ & $\begin{array}{l}-0.196 \\
(0.057)\end{array}$ \\
\hline real federal funds rate & & $\begin{array}{l}0.134 \\
0.051\end{array}$ & $\begin{array}{c}0.066 \\
(0.052)\end{array}$ & $\begin{array}{c}0.062 \\
(0.049)\end{array}$ \\
\hline $\begin{array}{l}\text { real federal funds rate } \\
\text { (one-year lag) }\end{array}$ & & & & $\begin{array}{c}0.107 \\
(0.077)\end{array}$ \\
\hline $\begin{array}{l}\text { real federal funds rate } \\
\quad \text { (two-year lag) }\end{array}$ & & & & $\begin{array}{l}-0.183 \\
(0.057)\end{array}$ \\
\hline R-squared & 0.221 & 0.213 & 0.225 & 0.236 \\
\hline
\end{tabular}

Notes: 2394 observations from 19 manufacturing industries, 9 regions, and 14 years. All standard errors are robust to contemporaneous correlation of the error terms across industry-region pairs. Fixed industry and fixed region effects included but not shown, as well as a control for the contemporaneous percent change in real GDP. In the birth equation, contemporaneous values of jobs created by continuing establishments are also included as well as one- and two-year lags. In the death equation, the analogous variables for jobs destroyed by continuing establishments are included. See text for details.

Based on both the birth and death results from Table 7, we do not believe our inflation results reflect changes in monetary policy. The federal-funds-rate coefficient is not statistically significant in either the birth or the death model when inflation is included. The inflation coefficients, however, remain strong when the federal funds rate is included. 


\section{Heterogeneity across industries and regions}

Figures 9 and 10 show that, for both our birth and death equations, yearly averages of predicted and actual averages match up reasonably well. Since the R2 values from the models estimated on disaggregated data are not particularly high, Figures 9 and 10 might mask considerable heterogeneity across industries or regions. We will show below that, despite this heterogeneity, our results appear robust across industries and regions.

Table 8 presents estimates of a birth and death equation. Each model contains the percent change in CPI and our real-business cycle controls, fully interacted by industry, as well as fixed industry and fixed region effects. Although there is strong evidence from both models that the inflation coefficients differ across industries, all of these coefficients are negative and many are statistically significant.

TABLE 8

Inflation-Coefficient Heterogeneity Across Industries (2-digit manufacturing industries by region, 1975-88)

\begin{tabular}{|c|c|c|c|c|}
\hline \multirow[b]{2}{*}{ Variable } & \multicolumn{2}{|c|}{ Birth Equation } & \multicolumn{2}{|c|}{ Death Equation } \\
\hline & Estimate & Std. Error & Estimate & Std. Error \\
\hline$\%$ D CPI for Food \& Tobacco & -0.131 & 0.046 & -0.138 & 0.067 \\
\hline$\%$ D CPI for Textile & -0.377 & 0.118 & -0.057 & 0.197 \\
\hline \% D CPI for Apparel & -0.110 & 0.076 & -0.099 & 0.189 \\
\hline$\%$ D CPI for Lumber & -0.180 & 0.089 & -0.162 & 0.121 \\
\hline$\%$ D CPI for Furniture & -0.161 & 0.091 & -0.014 & 0.088 \\
\hline$\%$ D CPI for Paper & -0.060 & 0.042 & -0.032 & 0.040 \\
\hline$\%$ D CPI for Printing & -0.064 & 0.077 & -0.187 & 0.072 \\
\hline$\%$ D CPI for Chemicals & -0.096 & 0.070 & -0.180 & 0.136 \\
\hline$\%$ D CPI for Petroleum & -0.065 & 0.032 & -0.420 & 0.099 \\
\hline \% D CPI for Rubber & -0.314 & 0.079 & -0.176 & 0.049 \\
\hline \% D CPI for Leather & -0.143 & 0.086 & -0.246 & 0.114 \\
\hline \% D CPI for Stone, Clay, \& Glass & -0.169 & 0.062 & -0.161 & 0.065 \\
\hline \% D CPI for Primary Metals & -0.096 & 0.044 & -0.315 & 0.063 \\
\hline$\%$ D CPI for Fabricated Metals & -0.121 & 0.049 & -0.150 & 0.039 \\
\hline \% D CPI for Non-electric Machinery & -0.276 & 0.066 & -0.303 & 0.055 \\
\hline \% D CPI for Electric Machinery & -0.214 & 0.046 & -0.218 & 0.035 \\
\hline \% D CPI for Transportation & -0.107 & 0.054 & -0.143 & 0.044 \\
\hline$\%$ D CPI for Instruments & -0.221 & 0.101 & -0.116 & 0.112 \\
\hline \% D CPI for Miscellaneous & -0.271 & 0.100 & -0.416 & 0.147 \\
\hline R-squared & 0.176 & & 0.269 & \\
\hline Wald Test for equality of inflation coefficients & $\chi^{2}(18)=9$ & $\mathrm{p}$-val<0.01 & $\chi^{2}(18)=8$ & $\mathrm{p}$-val<0.01 \\
\hline
\end{tabular}

Notes: 2394 observations from 19 manufacturing industries, 9 regions, and 14 years. Standard errors are robust to contemporaneous correlation of the error terms across industry-region pairs. Fixed industry and fixed region effects included but not shown. See text for details.

Birth equation: Dependent variable is the percent of the industry's regional employment created by new establishments. The control variables are the percent change in real GDP (current only) and the percent of the industry's regional employment created by existing establishments (current, one-year lag, and twoyear lag). All controls are fully interacted by region.

Death equation: Dependent variable is the percent of the industry's regional employment destroyed by dying establishments. The control variables are the percent change in real GDP (current only) and the percent of the industry's regional employment destroyed by continuing establishments (current, one-year lag, and two-year lag). All controls are fully interacted by region. 
Table 9 presents estimates of a birth and death equation analogous to those in Table 8, but where heterogeneity across regions is investigated. Once again, both models reveal statistically significant inflation-coefficient heterogeneity, but all of the inflation coefficients are negative and many are statistically significant.

\section{TABLE 9}

Inflation-Coefficient Heterogeneity Across Regions (2-digit manufacturing industries by region, 1975-88)

\begin{tabular}{lcccc}
\hline & \multicolumn{2}{c}{ Birth Equation } & \multicolumn{2}{c}{ Death Equation } \\
Variable & Estimate & Std. Error & Estimate & Std. Error \\
\hline \% D CPI for New England & -0.126 & 0.041 & -0.237 & 0.070 \\
\% D in CPI for Middle Atlantic & -0.050 & 0.040 & -0.107 & 0.052 \\
\% D in CPI for East North Central & -0.144 & 0.036 & -0.172 & 0.047 \\
\% D in CPI for West North Central & -0.276 & 0.094 & -0.281 & 0.119 \\
\% D in CPI for South Atlantic & -0.197 & 0.039 & -0.244 & 0.046 \\
\% D in CPI for East South Central & -0.137 & 0.040 & -0.155 & 0.049 \\
\% D in CPI for West South Central & -0.150 & 0.071 & -0.234 & 0.061 \\
\% D in CPI for Mountain & -0.206 & 0.087 & -0.044 & 0.130 \\
\% D in CPI for Pacific & -0.166 & 0.070 & -0.280 & 0.073 \\
R-squared & 0.157 & & 0.254 & \\
Wald Test for equality of inflation coefficients & $\mathrm{c} 2(8)=73, \mathrm{p}$-val<0.01 & $\mathrm{c} 2(8)=17, \mathrm{p}$-val=0.03 \\
\hline Notes: 2394 obsal
\end{tabular}

Notes: 2394 observations from 19 manufacturing industries, 9 regions, and 14 years. Standard errors are robust to contemporaneous correlation of the error terms across industry-region pairs. Fixed industry and fixed region effects included but not shown. See text for details.

Birth equation: Dependent variable is the percent of the industry's regional employment created by new establishments. The control variables are the percent change in real GDP (current only) and the percent of the industry's regional employment created by existing establishments (current, one-year lag, and twoyear lag). All controls are fully interacted by region.

Death equation: Dependent variable is the percent of the industry's regional employment destroyed by dying establishments. The control variables are the percent change in real GDP (current only) and the percent of the industry's regional employment destroyed by continuing establishments (current, one-year lag, and two-year lag). All controls are fully interacted by region.

In summary, although we find strong evidence of heterogeneity across industries and regions, this heterogeneity does not undermine our results. Estimating separate coefficients across industries and regions yielded no evidence to contradict our basic results.

\section{An alternative data source}

In this subsection, we use an alternative data source on business failures to further support our hypothesis regarding establishment deaths. As will be clear from our description of the data, important differences exist between the job-destruction data used earlier and the business-failures data we use here. Despite these differences between the two data sets, both data sets yield similar conclusions regarding inflation and firm or establishment turnover.

The Dun \& Bradstreet Corporation keeps statistics on business failures. The Dun \& Bradstreet business-failure statistics include: businesses that ceased operations following assignment or bankruptcy; ceased operations with losses to creditors after 
such actions as foreclosure or attachment; voluntarily withdrew leaving unpaid debts; were involved in court actions such as receivership, reorganization or arrangement; or voluntarily compromised with creditors. See Dun \& Bradstreet Corporation [1998] for details.

These data allow us to look at deaths in a manner that is completely different from the job destruction statistics presented earlier. First, we use data from calendar years 1968-97, which is the period over which our inflation measure overlaps with the business-failures data. Second, these business-failure statistics are defined at the firm level rather than the establishment level. Third, these business-failure statistics are the percent of firms that failed, rather than the percent of employment in firms that failed. Unfortunately, these business-failure statistics account for only a fraction of total business closings; business that discontinued operations after paying their creditors in full are not included.

The business-failures data have an important weakness. The coverage of the sample was extended in 1984 to include the following business sectors: agriculture, forestry and fishing; finance, insurance and real estate; and the services sector in its entirety. The results presented in this section, however, are stable across the 19681983 and 1984-1997 periods.

In Figure 11, we plot inflation and the number of business failures per 1,000 firms listed on the Dun \& Bradstreet database. Figure 11 appears similar to Figure 4; business failures are negatively correlated with inflation. It is particularly noteworthy that the business-failure rate is higher in the 1990s than in the late 1970s when the economy experienced both weak economic growth and high inflation.

In Table 10, we present regression models of the effect of inflation on the business-failure rate, including controls for real-GDP growth and a linear time trend. In addition to ordinary least-squares models, we present Prais-Winston models that account for an $\mathrm{AR}(1)$ error process. It is clear from the Durbin-Watson statistics and from the estimated $\mathrm{AR}(1)$ parameters that the business-failures data are serially correlated.

Although the inflation coefficients are unstable across specifications, the inflation coefficient is always estimated to be negative and statistically significant. Since the business-failures data are produced using a methodology that is substantially different from the methodology used for the job destruction data, we view the results in Table 10 as an important robustness check.

\section{CONCLUSIONS AND DIRECTIONS FOR FUTURE RESEARCH}

Using manufacturing data from 1973-88 we provide strong evidence that both jobs created by new establishments and jobs destroyed by dying establishments are negatively related to inflation. These relationships are not visible when considering net job flows, which may be masking the distributional effects that we document with gross flows. Moreover, these relationships do not appear to be driven by the real- 
business cycle, oil-price shocks, or monetary shocks, and they appear robust across industries, across regions, and throughout our time frame. Data on business failures from 1968-1997 provide additional empirical support. There are several possible explanations for the observed correlations. Regardless of the model used to explain the facts, one needs to prove the existence of a mechanism through which inflation may have real effects. In other words, one needs to establish a structural causal relationship between inflation and turnover.

\section{FIGURE 11}

\section{Inflation and Business Failures}

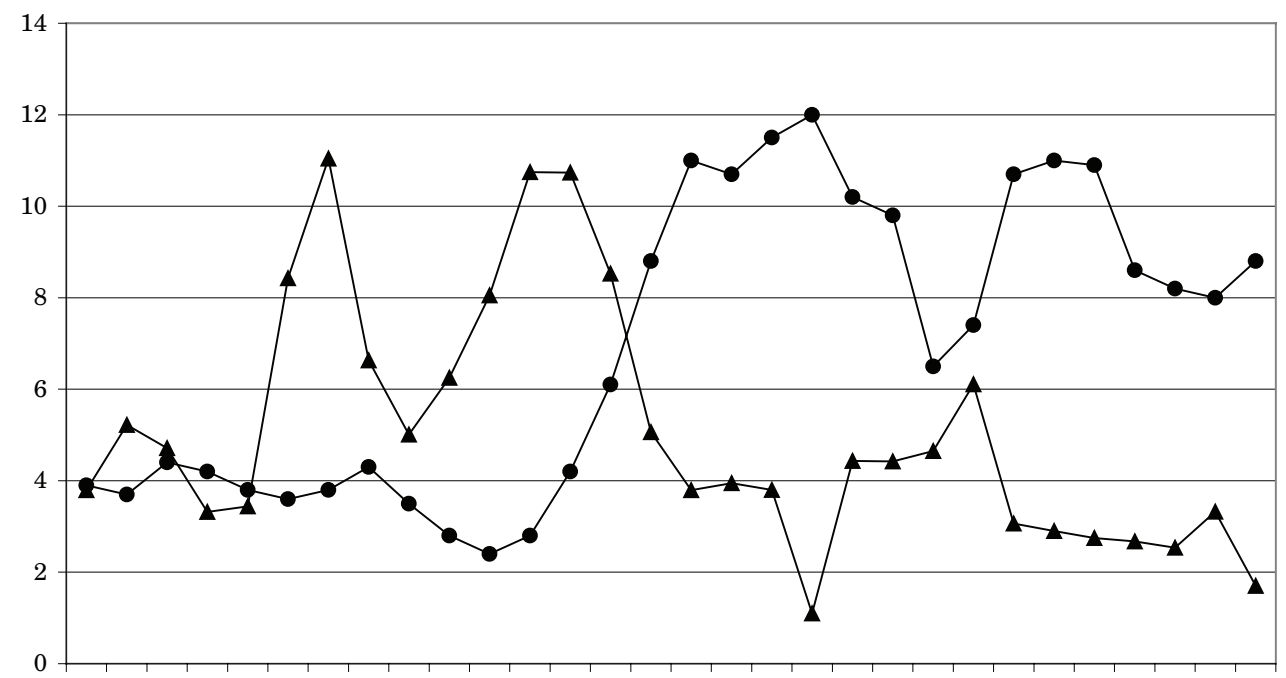

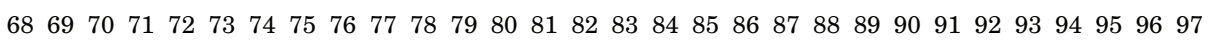
Year

$\%$ change in CPI $\bullet-$ business failures per 1,000 firms

There are several definitions of turnover, as Caves [1998] explains, that can be employed in research. Obviously, an extension to this work would be to investigate whether a similar relationship holds using other definitions. The same observation holds for other periods. But even if our results could be replicated in other time periods and other sectors of the economy, several important issues would remain. First, what are the characteristics of the establishments whose births and deaths are affected by inflation? Second, can our financial-markets hypothesis, our nominal-wage rigidities hypothesis, our market-power hypothesis, or any other hypothesis be tested directly? Third, do the changes in establishment turnover that are driven by changes in inflation have significant impact on aggregate productivity? Finally, another hypothesis to be considered is the possibility that changes in both turnover and inflation depend on a third, common factor. We leave these questions for future research. 
TABLE 10

The Effect of Inflation on Business Failures (annual Dun \& Bradstreet data, 1968-97)

\begin{tabular}{|c|c|c|c|c|}
\hline \multicolumn{5}{|c|}{ Dependent Variable: Business Failures per 1,000 firms } \\
\hline Variable & $\begin{array}{c}\text { Estimate } \\
\text { (Std. Error) }\end{array}$ & $\begin{array}{c}\text { Estimate } \\
\text { (Std. Error) }\end{array}$ & $\begin{array}{c}\text { Estimate } \\
\text { (Std. Error) }\end{array}$ & $\begin{array}{c}\text { Estimate } \\
\text { (Std. Error) }\end{array}$ \\
\hline intercept & 10.836 & 12.096 & 6.089 & 7.051 \\
\hline & (1.003) & $(1.274)$ & $(1.320)$ & $(1.575)$ \\
\hline$\%$ change in $\mathrm{CPI}$ & -0.772 & -0.835 & -0.464 & -0.516 \\
\hline & $(0.176)$ & $(0.176)$ & (1.153) & $(0.159)$ \\
\hline$\%$ change in real GDP & & -0.330 & & -0.190 \\
\hline & & $(0.213)$ & & (1.172) \\
\hline linear trend & & & 0.206 & 0.195 \\
\hline & & & $(0.046)$ & $(0.047)$ \\
\hline Durbin-Watson statistic & 0.387 & 0.438 & 0.437 & 0.428 \\
\hline $\mathrm{R}$-squared & 0.408 & 0.457 & 0.658 & 0.674 \\
\hline Dependent Variable: Busines & er 1,000 firms & (Prais-Winst & on Regressior & ns) \\
\hline Variable & $\begin{array}{c}\text { Estimate } \\
\text { (Std. Error) }\end{array}$ & $\begin{array}{c}\text { Estimate } \\
\text { (Std. Error) }\end{array}$ & $\begin{array}{c}\text { Estimate } \\
\text { (Std. Error) }\end{array}$ & $\begin{array}{c}\text { Estimate } \\
\text { (Std. Error) }\end{array}$ \\
\hline intercept & $\begin{array}{c}8.054 \\
(1.708)\end{array}$ & $\begin{array}{c}8.631 \\
(1.761)\end{array}$ & $\begin{array}{c}5.317 \\
(1.959)\end{array}$ & $\begin{array}{l}6.000 \\
(2.018)\end{array}$ \\
\hline$\%$ change in CPI & $\begin{array}{l}-0.314 \\
(0.115)\end{array}$ & $\begin{array}{l}-0.347 \\
(0.113)\end{array}$ & $\begin{array}{l}-0.304 \\
(0.115)\end{array}$ & $\begin{array}{l}-0.337 \\
(0.114)\end{array}$ \\
\hline$\%$ change in real GDP & & $\begin{array}{l}-0.135 \\
(0.083)\end{array}$ & & $\begin{array}{l}-0.133 \\
(0.084)\end{array}$ \\
\hline linear trend & & & $\begin{array}{c}0.183 \\
(0.096)\end{array}$ & $\begin{array}{c}0.175 \\
(0.097)\end{array}$ \\
\hline AR(1) parameter & 0.891 & 0.897 & 0.823 & 0.834 \\
\hline R-squared (transformed model) & 0.181 & 0.255 & 0.269 & 0.328 \\
\hline
\end{tabular}

Notes: 30 observations. See text for details.

\section{NOTES}

We gratefully acknowledge comments from the associate editor, James Butkiewicz, two anonymous referees, as well as seminar participants at the BLS, ITAM, the Center for Economic Studies, the University of Maryland, the University of Houston, Texas A\&M, Purdue University, and the 1999 SEA Meetings. In addition, we wish to thank Roger Farmer, Steve Fazzari, James Hamilton, James Morley, Chris Neely, Bruce Petersen, and Mika Saito for helpful conversations and comments on previous drafts. Any errors are solely ours. Earlier drafts had been circulated under the title "Inflation, Credit, and Establishment Turnover."

1. In general, our results are consistent with the literature in industrial organization on turnover. We find similar patterns of entry and exit of establishments. Dunne, Roberts, and Samuelson [1988] document, at the firm level, that industries with high entry rates also display high exit rates. For a survey, see Caves [1998].

2. For early and influential analyses, see Mundell [1965] and Tobin [1965], who note that inflation may lower the real interest rate by lowering the real return to holding money.

3. See also Bruno and Easterly [1998].

4. See Azariadis and Smith [1996] for a theoretical model in which credit is more difficult to obtain because of high inflation, thus reversing the Mundell-Tobin effect. Azariadis and Smith [1996] construct a model in which there is adverse selection in financial markets. When inflation is high, incentive 
compatibility requires that credit constraints on "good" borrowers become tighter, reducing total availability of credit.

5. See Table 8 for a list of the nineteen Census two-digit industries and see Table 9 for a list of the nine Census regions.

6. Federal funds rate observations are available through the Federal Reserve Bank of St. Louis web site at www.stls.frb.org.

7. This method treats employment expansions and contractions symmetrically. Using this method, percent changes can range from $-200 \%$ to $200 \%$. If we use the previous year's employment in the denominator, percent changes can be as low as $-100 \%$ with no upper bound.

8. Since we are using time-series data, serial correlation might also be a concern. Correcting for an AR(1) process using aggregate manufacturing data does not affect our results. Correcting for a common $\mathrm{AR}(1)$ parameter across all industries and regions using disaggregated data also does not affect our results.

9. The data are sorted by industry-region pair, then by time.

10. To be conservative, we normalize our standard errors by $\mathrm{n}-\mathrm{k}$ ( $\mathrm{k}$ is the number of parameters estimated) rather than by n. Green [1997] notes that neither generates unbiased variance estimation.

11. Feasible Generalized Least Squares (FGLS) requires $\hat{\Omega}$ to be inverted, which is impossible when the number of cross-sectional units is larger than the number of time periods. FGLS is therefore impossible for our data. See Beck and Katz [1995] for details, including Monte Carlo simulations of the small-sample properties of the standard errors.

12. The data set covers the entire manufacturing sector, 20 two-digit industries, where the industries food and tobacco have been combined into one industry.

13. A test that current through two-year lags of job creation by existing establishments all have no effect on births yields a p-value of 0.08 .

14. See, for instance, Mork [1989] and Hamilton [2003].

15. The CPI-UX1 is used to convert nominal returns into real returns.

\section{REFERENCES}

Akerlof, G. A., Dickens, W. T. and Perry G. L. The Macroeconomics of Low Inflation. Brookings Papers on Economic Activity, 1996, 1-76.

Altonji, J. G. and Devereux, P. J. The Extent and Consequences of Downward Nominal Wage Rigidity. NBER Working Paper No. W7236, 1999.

Acemoglu, Daron. Credit Market Imperfections and Persistent Unemployment. NBER Working Paper No. 7938, October 2000.

Azariadis, C. and Smith, B. D. Private Information, Money, and Growth: Indeterminacy, Fluctuations, and the Mundell-Tobin Effect. Journal of Economic Growth, 1996, 309-332.

Beck, N. and Katz, J. N. What to Do (and not to do) with Time-Series Cross-Section Data. American Political Science Review, 1995, 634-47.

Boudoukh, J. and Richardson M. Stock Returns and Inflation: A Long-Horizon Perspective. American Economic Review, 1993, 1346-55.

Bruno, M. and Easterly, W. Inflation Crises and Long-Run Growth. Journal of Monetary Economics, 1998, 3-26.

Bruno, M. and Meridor, L. The Costly Transition from Stabilization to Sustainable Growth: Israel's Case, in Lessons of Economic Stabilization and its Aftermath, edited by M. Bruno et al.. MIT Press, 1991.

Bullard, J. and Keating, J. The Long-Run Relationship between Inflation and Output in Postwar Economies. Journal of Monetary Economics, 1995, 477-96.

Campbell, C. M., III and Kamlani, K. S. The Reasons for Wage Rigidity: Evidence from a Survey of Firms. Quarterly Journal of Economics. 1997, 759-89.

Card, D. and Hyslop, D. Does Inflation Grease the Wheels of the Labor Market? in Reducing Inflation: Motivation and Strategy, edited by C. D. Romer and D. H. Romer, National Bureau of Economic Research Studies in Business Cycles, 1997.

Caves, R. E. Industrial Organization and New Findings on the Turnover and Mobility of Firms. Journal of Economic Literature, 1998, 1947-1982. 
Chirinko, R. S. and Fazzari, S. M. Market Power and Inflation. Review of Economics and Statistics, 2000, 509-13.

Choi, S., Smith, B. D. and Boyd, J. H. Inflation, Financial Markets, and Capital Formation. Federal Reserve Bank of St. Louis Review, 1996, 9-35.

Davis, S. J. and Haltiwanger, J. C. Driving Forces and Employment Fluctuations. NBER Working Paper no. W5775, 1996.

Davis, S. J., Haltiwanger, J. C. and Schuh, S. Job Creation and Destruction. MIT Press, 1996.

Davis, S. J. and Haltiwanger, J. C. Sectoral Job Creation and Destruction Responses to Oil Price Changes. NBER Working Paper no. W7095, 1999.

Dun \& Bradstreet Corporation. The Business Failure Record. Dun \& Bradstreet Corporation, 1998.

Dunne, T., Roberts, M. J. and Samuelson, L. Patterns of Firm Entry and Exit in U.S. Manufacturing Industries. Rand Journal of Economics, 1988, 495-519.

Fama, E. F. Term-Structure Forecasts of Interest Rates, Inflation, and Real Returns. Journal of Monetary Economics, 1990, 59-76.

Fama, E. F. and Schwert, W. G. Asset Returns and Inflation. Journal of Financial Economics, 1977, 115-46.

Foster, L., Haltiwanger, J. C. and Krizan, C. J. Aggregate Productivity Growth: Lessons from Microeconomic Evidence. NBER Working Paper no. W6803, 1998.

Greene, W. H. Econometric Analysis: 3d edition, Upper Saddle River, NJ: Prentice-Hall, 1997.

Greenwood, J. and Jovanovic, B. The IT Revolution and the Stock Market. NBER Working Paper no. W6931, 1999.

Hamilton, J. D. What is an Oil Shock? Journal of Econometrics, 2003, 363-398

Kandel, S., Ofer, A. R. and Sarig, O. Real Interest Rates and Inflation: An Ex-Ante Empirical Analysis. Journal of Finance, 1996, 205-25.

Lebow, D. E., Saks, R. E. and Wilson, B. A. Downward Nominal Wage Rigidity: Evidence from the Employment Cost Index. Federal Reserve Board FEDS paper no. 1999-32, 1999.

Mork, K. A. Oil Prices and the Macroeconomy When Prices Go Up and Down: An Extension of Hamilton's Results. Journal of Political Economy, 1989, 740-744.

Mundell, R. Growth, Stability, and Inflationary Finance. Journal of Political Economy, 1965, 97-109.

Scarpetta, S., Hemmings, P., Tressel T. and Woo J. The Role of Policy and Institutions for Productivity and Firm Dynamics: Evidence from Micro and Industry Data. Working Paper no. 329, OECD, Paris, 2002.

Spletzer, J. R. The Contribution of Establishment Births and Deaths To Employment Growth. Journal of Business and Economic Statistics, 2000, 113-126.

Tobin, J. Money and Economic Growth. Econometrica, 1965, 671-684.

Tommasi, M. On High Inflation and the Allocation of Resources. Journal of Monetary Economics, 1999, 401-421. 